\title{
Comparing passive leg raising and suprasystolic ankle occlusion responses to quantify age-related microcirculatory status
}

\author{
Comparação das respostas da elevação passiva da perna e da oclusão suprasistolica no \\ tornozelo para quantificar o status microcirculatório em função da idade
}

\author{
Henrique Silva ${ }^{1,2}$, Hugo Ferreira ${ }^{3}$, Julia Bujan ${ }^{4}$ and L Monteiro Rodrigues ${ }^{1,2}$ \\ ${ }^{1}$ CBIOS - Universidade Lusófona's Research Center for Biosciences and Health Technologies, \\ Campo Grande 376, 1749-024, Lisboa, Portugal \\ ${ }^{2}$ Pharmacol. Sc Depart - Universidade de Lisboa, School of Pharmacy, Lisboa, Portugal \\ ${ }^{3}$ IBEB - Universidade de Lisboa, Faculty of Sciences, Lisboa, Portugal \\ ${ }^{4}$ Faculty of Medicine, Universidad Alcalá de Henares, Madrid, Spain \\ Email: henrique.silva@ulusofona.pt
}

\begin{abstract}
The skin provides an easy accessible vascular network to assess microcirculation by laser Doppler flowmetry (LDF), and transcutaneous (tc) gasometry, widely known techniques used for this purpose. the objective of this study was to assess and compare the microcirculation status of different age subjects, knowing that the ageing process progressively affects macro and microcirculatory vessels. We've chosen to compare dynamical responses to two provocation tests - passive leg raising (PLR) and ankle occlusion - in 59 healthy subjects, 35 young (22.1 \pm 3.7 years old.) in Group 1, and 24 older (50.8 \pm 7.6 years old.) in Group 2, selected after informed consent. Local blood flow, tcpO2 and transepidermal water loss (TEWL) were measured in distal locations of the lower limb. PLR and ankle occlusion significantly reduced blood flow and tcpO2 in both groups, while no changes were found for TEWL. While the magnitude of the hyperemic response was found to be significantly reduced in group 2 , no differences were found during ankle occlusion. tcpO2-dependent parameters were also significantly different between groups. These results seem to confirm the usefulness of these experimental models to distinguish the microcirculatory function of subjects with different ages, with PLR being more sensible in detecting age-related changes.
\end{abstract}

Keywords: Vascular ageing; PLR; suprasystolic occlusion; LDF; tcpO2

\footnotetext{
Resumo

A pele fornece uma rede vascular de fácil acesso para avaliar a microcirculação por fluxometria por laser Doppler (FLD) e gasimetria transcutânea (tc), técnicas amplamente utilizadas para esta finalidade. O nosso objetivo foi avaliar e comparar o estado microcirculatório de indivíduos de diferentes idades disciplinas em geral, sabendo que o processo de envelhecimento afeta progressivamente os vasos da macro e microcirculação. Escolhemos comparar as respostas dinâmicas a 2 testes de provocação - elevação passiva da perna (EPP) e oclusão ao nível do tornozelo em 59 indivíduos saudáveis, 35 jovens $(22,1 \pm$ 3,7 anos) no grupo 1, e 24 mais velhos (50,8 \pm 7,6 anos) no grupo 2, seleccionados após consentimento informado. O fluxo sanguíneo local, a tcpO2 e perda transepidérmica de água (PTEA) foram medidos em zonas distais do membro inferior. A EPP e a oclusão reduziram significativamente o fluxo sanguíneo e tcpO2 em ambos os grupos, enquanto nenhuma alteração foi encontrado para PTEA. Embora tenha sido encontrada uma magnitude da resposta hiperémica significativamente reduzida no grupo 2, não foram encontradas diferenças durante a oclusão ao nível tornozelo. Os parâmetros dependentes de tcpO2 foram também significativamente diferentes entre grupos. Estes resultados parecem confirmar a utilidade desses modelos experimentais para distinguir a função microcirculatória de indivíduos com diferentes idades, sendo a EPP mais sensível na deteção de mudanças relacionadas com a idade.
}

Palavras-chave: Envelhecimento vascular; EPP; oclusão suprassistólica; FLD; tcpO2 


\section{Introduction}

Microcirculation is determinant for a proper delivery of oxygen and nutrients to the tissues, as well as for the removal of cellular waste and carbon dioxide. Therefore, tissue functionalities are dependent on an adequate microcirculatory perfusion ${ }^{[1]}$. The ageing process normally involves as many as varied physiological changes, also affecting macro and microcirculation vessels which progressively modify its function, especially at peripheral territories ${ }^{[2]}$. The skin provides an easily accessible vascular network to study microcirculatory function both in physiological and pathophysiological conditions ${ }^{[3]}$. Laser Doppler Flowmetry (LDF) and transcutaneous (tc) gasimetry are among some of the most widely employed techniques to assess this microcirculatory status ${ }^{[4-6]}$. However, standardization of procedures and measuring conditions is lacking ${ }^{[7-10]}$, which justifies their limited use and their limited diagnostic utility. Since the measurement of resting microcirculation does not provide relevant information of the microcirculation, "provocation" tests are often used to increase the sensitivity of these quantification techniques. By changing the resting perfusion conditions, local, regional or systemic compensatory responses can be elicited and easily quantified ${ }^{[5]}$. The tests most used to date are limb occlusion ${ }^{[1]}$, postural changes ${ }^{[12]}$, oxygen breathing ${ }^{[13]}$, and drug applications ${ }^{[14]}$. Attending to our previous experience in exploring methods to quantitatively describe the human in vivo peripheral vascular function, in the present paper, we assess and compare the vascular response of healthy subjects with different ages to two provocation maneuvers known to be used with this purpose as stress tests - passive leg raising and suprasystolic ankle occlusion.

\section{Materials and Methods}

59 healthy subjects, both genders, participated in this study after informed written consent. They were grouped according to their age in group 1, between 18 and $35(n=35,22.1 \pm 3.7)$ years old and group 2 , between 40 and $65(n=24,50.8 \pm 7.6)$ years old. Experiments took place in a room with controlled temperature $\left(21 \pm 2{ }^{\circ} \mathrm{C}\right)$ and humidity $(40-60 \%)$. Prior to measurements, individuals acclimatized for 20 minutes in the sitting position with their feet exposed. Two pro-

\section{Introdução}

A microcirculação é determinante para um fornecimento adequado de oxigénio e nutrientes para os tecidos, bem como para a remoção do dióxido de carbono e metabolitos celulares. Como tal, as funcionalidades tecidulares são dependentes de uma perfusão microcirculatória adequada ${ }^{[1]}$. O processo de envelhecimento normalmente envolve numerosas e variadas alterações fisiológicas, afetando também os vasos da macro e microcirculação cuja função é modificada progressivamente, especialmente em territórios periféricos ${ }^{[2]}$. A pele fornece uma rede vascular de fácil acesso para estudar a função microcirculatória, tanto em condições fisiológicas como fisiopatológicas ${ }^{[3]}$. A fluxometria por laser Doppler (FLD) e a gasimetria transcutânea (tc) estão entre algumas das técnicas mais amplamente utilizadas para avaliar este estado da microcirculação ${ }^{[4-6]}$. No entanto, a padronização de procedimentos e condições de medição está em falta ${ }^{[7-10]}$, o que justifica a sua utilização limitada bem como a sua limiatada utilidade diagnóstica. Uma vez que a medição da microcirculação em repouso não fornece informações relevantes acerca da microcirculação, são muitas vezes utilizados testes de "provocação" para aumentar a sensibilidade destas técnicas de quantificação. Ao alterar as condições de perfusão em repouso, estes testes provocam respostas compensatórias, tanto locais, regionais como sistémicas, e que são facilmente quantificadas ${ }^{[5]}$. Os testes mais usados até agora têm sido a oclusão de um membro ${ }^{[1]}$, alterações posturais ${ }^{[12]}$, respiração de oxigénio ${ }^{[13]}$, e aplicação de fármacos ${ }^{[14]}$. Atendendo à nossa experiência anterior em explorar métodos para descrever quantitativamente a função vascular periférica in vivo no ser humano, no presente trabalho, avaliamos e comparamos a resposta vascular de indivíduos saudáveis com idades diferentes para duas manobras de provocação - elevação passiva da perna e oclusão tornozelo suprassitólica, conhecidos por serem utilizados como testes de provocação para esta finalidade.

\section{Materiais e métodos}

59 indivíduos saudáveis de ambos os sexos participaram deste estudo após terem dado o seu consentimento informado por escrito. Foram distribuídos de acordo com sua idade no grupo 1, entre 18 e 35 anos ( $n$ $=35,22.1 \pm 3.7)$ e no grupo 2 , entre 40 e 65 anos (n $=24,50.8 \pm 7.6$ ). Os procedimentos ocorreram numa sala com temperatura $\left(21 \pm 2^{\circ} \mathrm{C}\right)$ e humidade $(40-60 \%)$ controladas. Antes das medições, os indivíduos aclimatizaram durante 20 minutos na posição sentada com os 
tocols already described in detail ${ }^{[15]}$ were applied in this sequence, suprasystolic ankle occlusion and passive leg raising (PLR). Each protocol consisted of three recording phases - resting, provocation and recovery. All procedures complied with the Helsinki declaration and subsequent amendments ${ }^{[16]}$. The experimental variables, measured in distal locations of the lower limb, were blood flow, expressed in arbitrary units (AU) by LDF (Periflux 5010, Stockholm, Sweden) and tcpO ${ }_{2}$, expressed in $\mathrm{mmHg}$ by transcutaneous gasimetry (Periflux 5040, Stockholm, Sweden). From both blood flow and tcpO values several relevant parameters were chosen for group comparison ${ }^{[15]}$ as follows:

- resting flow (RF) - the mean flux signal level during the whole resting phase; biological zero (BZ) - the remaining flux signal during occlusion; peak flow (PF) - the highest flux value observed during the hyperemia; percent variation from resting flow to biological zero (RF-BZ); Percent variation from biological zero to peak flow (BZ-PF); percent variation from resting flow to peak flow (RF-PF); Area of occlusion (AO) - Area under the curve of the flow signal during the occlusion period; area of hyperemia (AH) - area under the curve of the of the flow signal during the hyperemic period; ratio of the area of hyperemia and the area of occlusion (AH/AO); decrement velocity ( $\mathrm{dV})$ - slope of the tcpO curve between 10 and 14 minutes for the PLR protocol and between 10 and 13 minutes for the occlusion protocol; increment velocity (iV) - slope of the tcpO $\mathrm{O}_{2}$ curve between 20 and 24 minutes for the PLR protocol and between 13 and 16 minutes for the occlusion protocol. Transepidermal water loss (TEWL), which quantifies the amount of water lost from the epidermis to the exterior, was also measured to explore the influence of local perfusion conditions on the water dynamics. TEWL is expressed in $\mathrm{g} / \mathrm{h} / \mathrm{m}^{2}$, and was measured using a Tewameter TM300 evaporimeter (Courage \& Khazaka, Cologne, Germany).

The selected variables and parameters were compared between groups by the Wilcoxon signed-rank test (IBM SPSS Statistics for Windows, version 20.0, Armonk, NY: IBM Corp). A 95\% confidence interval was adopted.

\section{Results and Discussion}

During PLR, both blood flow and tcpO $\mathrm{O}_{2}$ decreased significantly in both groups, as shown in Table 1. This perfusion reduction is explained by the gravitational transfer of blood that occurs when the leg is passively raised from supine, from the peripheral venous compartment to the central circulatory compartment ${ }^{[12]}$. pés expostos. Foram aplicados dois protocolos já descritos em detalhe ${ }^{[15]}$ por esta ordem, oclusão suprassistólica ao nível do tornozelo e elevação passiva da perna (EPP). Cada protocolo consistiu de três fases de registo - repouso, provocação e recuperação. Todos os procedimentos cumpriram com a declaração de Helsínquia e alterações posteriores ${ }^{[16]}$. As variáveis experimentais, medidas em locais distais do membro inferior, foram o fluxo sanguíneo, expresso em unidades arbitrárias (UA) por FLD (Periflux 5010, Estocolmo, Suécia) e tcpO, expressa em $\mathrm{mmHg}$ por gasimetria transcutânea (Periflux 5040, Estocolmo, Suécia). Dos valores do fluxo sanguíneo como de tcpO foram escolhidos vários parâmetros relevantes para comparação de grupos ${ }^{[15]}$ como se segue:

- fluxo em repouso (FR) - o nível do sinal de fluxo significativo durante toda a fase de repouso; zero biológico (ZB) - o sinal de fluxo remanescente durante a oclusão; pico de fluxo (PF) - o valor de fluxo mais elevado observada durante a hiperémia; variação percentual do fluxo em repouso para o zero biológico (FR-ZB); variação percentual desde o zero biológico para o pico de fluxo (ZB-PF); variação percentual de fluxo em repouso para o pico de fluxo (FR-PF); área da oclusão (AO) - área sob a curva do sinal de fluxo durante o período de oclusão; área da hiperémia $(\mathrm{AH})$ - a área sob a curva do sinal de fluxo durante o período de hiperémia; razão entre a área da hiperémia e a área da oclusão $(\mathrm{AH} / \mathrm{AO})$; velocidade de decremento $(\mathrm{Vr})$ - declive da curva de tcpO entre os minutos 10 e 14 para o protocolo de EPP e entre os minutos 10 e 13 para o protocolo de oclusão; velocidade de incremento (Vi) - declive da curva de tcpO $\mathrm{O}_{2}$ entre os minutos 20 e 24 para o Protocolo de EPP e entre os minutos 13 e 16 para o protocolo de oclusão.

A perda transepidérmica de água (PTEA), que quantifica a quantidade de água perdida da epiderme para o exterior, foi também medida para explorar a influência das condições de perfusão local sobre a dinâmica da água. PTEA é expressa em $\mathrm{g} / \mathrm{h} / \mathrm{m}^{2}$, e foi medida usando um evaporímetro Tewameter TM300 (Courage \& Khazaka, Colónia, Alemanha).

As variáveis e parâmetros selecionados foram comparados entre grupos pelo teste de Wilcoxon para amostras emparelhadas (IBM SPSS Statistics for Windows, versão 20.0, Armonk, NY: IBM Corp). Foi adotado um intervalo de confiança de $95 \%$ foi adotado.

\section{Resultados e discussão}

Durante a elevação passiva da perna, tanto o fluxo sanguíneo como tcpO $\mathrm{O}_{2}$ diminuíram significativamente em ambos os grupos, como se mostra na tabela 1 . Esta redução de perfusão é explicada pela transferência gravitacional de sangue que ocorre quando a perna é levantada passivamente da posição supina, a partir do 
Non-significant changes in TEWL were noted for both groups, although following opposite directions. Significant differences between resting and recovery phases were found for blood flow in both groups. compartimento venoso periférico para o compartimento circulatório central ${ }^{[12]}$. As alterações não significativas na PTEA foram observados nos dois grupos, embora seguindo direções opostas. As diferenças significativas entre as fases de repouso e recuperação foram encontrados para o fluxo sanguíneo em ambos os grupos.

Table 1/ Tabela 1. Results (mean \pm standard deviation) of each studied variable for the last five minutes of each phase of the passive leg raising test. Statistical comparison for resting phase. * - statistically significant $(\mathrm{p}<0.05)$

Resultados (média \pm desvio-padrão) de cada variável estudada para os últimos 5 minutos de cada fase do protocolo de elevação passiva da perna. Comparação estatística para a fase de repouso. * -estatisticamente significativo $(\mathrm{p}<0.05)$.

\begin{tabular}{|c|c|c|c|c|c|c|c|}
\hline \multicolumn{8}{|c|}{ PLR / EPP } \\
\hline \multirow{2}{*}{\multicolumn{2}{|c|}{ Variable / Variável }} & \multicolumn{3}{|c|}{ Group 1 / Grupo 1} & \multicolumn{3}{|c|}{ Group 2 / Grupo 2} \\
\hline & & Resting / & Provocation / & Recovery / & Resting / & Provocation / & Recovery / \\
\hline \multirow{2}{*}{$\begin{array}{c}\text { TEWL / PTEA } \\
\left(\mathrm{g} / \mathrm{h} / \mathrm{m}^{2}\right)\end{array}$} & $\begin{array}{l}\text { mean } \pm \mathrm{sd} / \\
\text { media } \pm \mathrm{dp}\end{array}$ & $5.7 \pm 2.0$ & $6.2 \pm 2.6$ & $5.9 \pm 2.1$ & $8.0 \pm 2.8$ & $7.4 \pm 3.9$ & $7.7 \pm 4.1$ \\
\hline & $\begin{array}{l}\mathrm{p} \text {-value / } \\
\text { valor } \mathrm{p}\end{array}$ & - & 0.112 & 0.955 & - & 0.183 & 0.681 \\
\hline \multirow{2}{*}{$\begin{array}{c}\text { Blood flow (AU) / } \\
\text { Fluxo sanguíneo } \\
\text { (UA) }\end{array}$} & $\begin{array}{c}\text { mean } \pm \mathrm{sd} / \\
\text { media } \pm \mathrm{sp}\end{array}$ & $12.7 \pm 11.3$ & $7.2 \pm 4.4$ & $10.8 \pm 6.8$ & $25.4 \pm 18.1$ & $11.3 \pm 5.4$ & $14.4 \pm 10.3$ \\
\hline & $\begin{array}{l}\mathrm{p} \text {-value / } \\
\text { valor } \mathrm{p}\end{array}$ & - & $<0.001 *$ & $0.011^{*}$ & - & $<0.001^{*}$ & $<0.001 *$ \\
\hline \multirow{2}{*}{$\begin{array}{c}\text { tcpO }_{2} \\
(\mathrm{mmHg})\end{array}$} & $\begin{array}{l}\text { mean } \pm \mathrm{sd} / \\
\text { media } \pm \mathrm{dp}\end{array}$ & $75.5 \pm 15.9$ & $44.3 \pm 17.1$ & $73.4 \pm 17.0$ & $65.9 \pm 14.7$ & $48.5 \pm 13.9$ & $64.6 \pm 16.3$ \\
\hline & $\begin{array}{l}\mathrm{p} \text {-value / } \\
\text { valor } \mathrm{p}\end{array}$ & - & $<0.001^{*}$ & $0.008^{*}$ & - & $<0.001^{*}$ & 0.161 \\
\hline
\end{tabular}

During ankle occlusion, both blood flow and tcpO $\mathrm{O}_{2}$ decreased very significantly during the provocation phase in both groups, as shown in Table 2. This perfusion decrease seems to be evoked by the mechanical compression of the arteries supplying the lower limb. Interestingly, an increase in TEWL was noted in both groups, although non-significant. This phenomenon was reported before and may be linked to the redistribution of local Starling forces following occlusion ${ }^{[4]}$. The initial perfusion conditions were restored by the end of the recovery period, as noted by the non-significant changes between resting and recovery phases for all variables. As shown in Table 3, during PLR a higher resting perfusion was recorded for group 2 relative to group 1, as noted in the significantly higher resting flow (RF). This suggests a difference in activity of the mechanisms regulating blood flow in subjects with different ages. The biological zero (BZ), the percent variation from resting flow to biological zero (RF-BZ), and the area of occlusion (AO) were also found to be significantly higher in group 2. While no differences were found for peak flow $(\mathrm{PF})$, significantly lower values were found for BZ-PF,
Durante a oclusão ao nível do tornozelo, tanto o fluxo sanguíneo como tcpO $\mathrm{O}_{2}$ diminuíram muito significativamente durante a fase de provocação em ambos os grupos, como mostrado na tabela 2. Esta redução de perfusão parece ser evocada pela compressão mecânica das artérias que irrigam o membro inferior. Curiosamente, foi observado um aumento na PTEA em ambos os grupos, embora não significativa. Este fenómeno foi observado anteriormente e poderá provavelmente estar ligado à redistribuição de forças locais de Starling após a oclusão ${ }^{[4]}$. As condições iniciais de perfusão foram restauradas até ao final do período de recuperação, como foi observado pelas alterações não significativas entre as fases de repouso e recuperação para todas as variáveis.

Como mostrado na tabela 3, durante a EPP foi registada uma perfusão de repouso mais elevada para o grupo $2 \mathrm{em}$ relação ao grupo 1, como observado no valor de fluxo em repouso (FR) significativamente maior. Isto sugere uma diferença na atividade dos mecanismos que regulam o fluxo sanguíneo em sujeitos com idades diferentes. O zero biológico (ZB), a variação percentual do fluxo em repouso para zero biológico (FR-ZB) e a área de oclusão (AO) também foram significativamente maiores no grupo 2. Enquanto não foram encontradas diferenças para o pico de fluxo (PF), foram encontrados valores significativamente mais baixos para $\mathrm{ZB}-\mathrm{PF}, \mathrm{FR}-\mathrm{PZ}$, $\mathrm{AH}$ e $\mathrm{AH} / \mathrm{AO}$ do grupo 2. Isto sugere que apesar de terem 
RF-PZ, AH and AH/AO in group 2. This suggests that, despite having a higher resting perfusion, older subjects suffer a higher perfusion decrease during leg raising, display a less exuberant response on the onset of the recovery phase, and show a diminished recovery capacity compared to younger subjects. uma perfusão mais elevada em repouso, os indivíduos mais velhos sofrem uma diminuição de perfusão maior durante elevação da perna, exibem uma resposta menos exuberante no início da fase de recuperação e mostram uma capacida-

Table 2/ Tabela 2. Results (mean \pm standard deviation) of each studied variable for the last five minutes of each phase of the ankle occlusion protocol. Statistical comparison for resting phase. ${ }^{*}$ - statistically significant $(\mathrm{p}<0.05)$

Resultados (média \pm desvio-padrão) de cada variável estudada para os últimos 5 minutos de cada fase do protocolo de oclusão ao nível do tornozelo. Comparação estatística para a fase de repouso. * -estatisticamente significativo $(\mathrm{p}<0.05)$

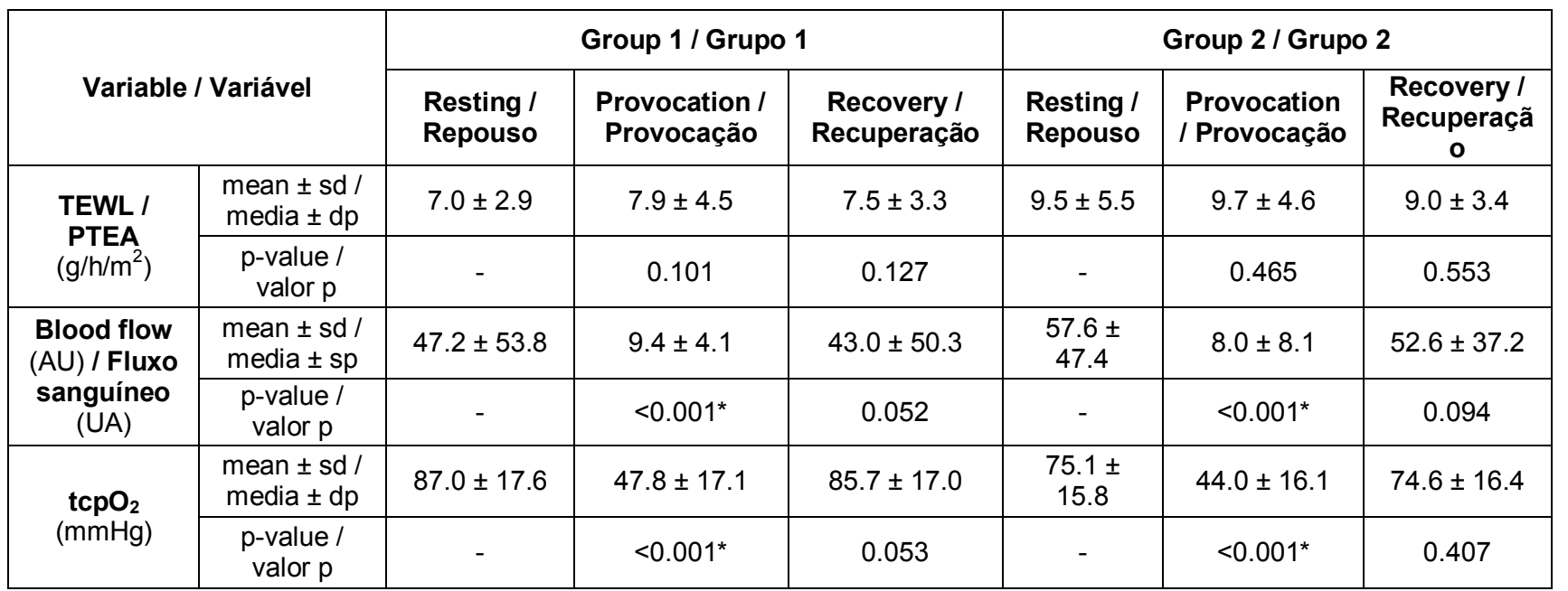

Table 3 / Tabela 3. Results (mean \pm standard deviation) registered for each parameter of each group with both protocols. * - statistically significant $(\mathrm{p}<0.05)$

Resultados (media $\pm \mathrm{dp}$ ) registados para cada parâmetro de cada grupo com ambos os protocolos. * -estatisticamente significativo $(\mathrm{p}<0.05)$

\begin{tabular}{|c|c|c|c|c|c|c|c|c|}
\hline \multicolumn{4}{|c|}{ PLR / EPP } & \multicolumn{3}{|c|}{ Occlusion / Oclusão } & \multicolumn{2}{|c|}{$\begin{array}{l}\text { p-value (PLR vs } \\
\text { Occlusion) / valor p } \\
\text { (EPP vs Oclusão) }\end{array}$} \\
\hline $\begin{array}{l}\text { Parameter I } \\
\text { Parâmetro }\end{array}$ & Group 1 / Grupo 1 & Group 2 / Grupo 2 & $\begin{array}{l}\text { p-value I } \\
\text { valor } p\end{array}$ & $\begin{array}{c}\text { Group } 1 \text { / Grupo } \\
1\end{array}$ & $\begin{array}{c}\text { Group } 2 \text { / Grupo } \\
2\end{array}$ & $\begin{array}{l}p \text {-value I } \\
\text { valor } p\end{array}$ & $\begin{array}{l}\text { Group } 1 \text { I } \\
\text { Grupo } 1\end{array}$ & $\begin{array}{l}\text { Group } 2 \text { I } \\
\text { Grupo } 2\end{array}$ \\
\hline RF / FR & $14.2 \pm 12.2$ & $26.6 \pm 17.0$ & $0.011^{*}$ & $45.1 \pm 48.0$ & $56.9 \pm 43.5$ & 0.212 & $<0.001^{*}$ & $0.028^{*}$ \\
\hline BZ / ZB & $7.1 \pm 4.1$ & $11.8 \pm 6.1$ & $0.002^{*}$ & $5.7 \pm 2.5$ & $5.9 \pm 2.5$ & 0.975 & 0.245 & $<0.001^{*}$ \\
\hline PF & $59.8 \pm 44.9$ & $46.7 \pm 46.9$ & 0.551 & $172.4 \pm 118.3$ & $175.6 \pm 82.0$ & 0.431 & $<0.001^{*}$ & $<0.001^{*}$ \\
\hline $\begin{array}{c}\text { RF-BZ / FR- } \\
\text { ZB }\end{array}$ & $-39.6 \pm 18.4$ & $-51.2 \pm 22.4$ & $0.024^{*}$ & $-74.6 \pm 18.8$ & $-79.0 \pm 20.2$ & 0.206 & $<0.001^{*}$ & $<0.001^{*}$ \\
\hline $\begin{array}{c}\text { BZ-PF / ZB- } \\
\text { PF }\end{array}$ & $897.5 \pm 837.7$ & $405.9 \pm 300.6$ & $0.006^{*}$ & $2819.8 \pm 1687.4$ & $3121.3 \pm 1446.3$ & 0.262 & $<0.001^{*}$ & $<0.001^{*}$ \\
\hline $\begin{array}{c}\text { RF-PF / FR- } \\
\text { PF }\end{array}$ & $430.5 \pm 405.0$ & $186.5 \pm 157.3$ & $0.001^{*}$ & $485.2 \pm 302.9$ & $419.7 \pm 371.0$ & 0.169 & 0.182 & $0.025^{*}$ \\
\hline AO & $5034.8 \pm 8445.5$ & $7457.4 \pm 6275.3$ & $0.047^{*}$ & $6304.6 \pm 8065.0$ & $8331.0 \pm 6938.4$ & 0.210 & 0.291 & 0.664 \\
\hline $\mathbf{A H}$ & $1864.5 \pm 2370.1$ & $719.3 \pm 5192.8$ & $0.014^{*}$ & $6274.1 \pm 8280.5$ & $6308.6 \pm 8538.3$ & 0.450 & $<0.001^{*}$ & $<0.001^{*}$ \\
\hline AH/AO & $0.9 \pm 1.0$ & $0.3 \pm 0.9$ & $0.007^{*}$ & $1.8 \pm 2.4$ & $0.9 \pm 1.2$ & 0.298 & $0.010^{*}$ & $0.002^{*}$ \\
\hline $\begin{array}{c}\mathbf{d V} / \mathbf{V d} \\
(\mathrm{mmHg} / \mathrm{min})\end{array}$ & $-7.7 \pm 3.0$ & $-4.3 \pm 2.2$ & $<0.001^{*}$ & $-24.3 \pm 5.8$ & $-19.2 \pm 17.5$ & $0.021^{*}$ & $<0.001^{*}$ & $<0.001^{*}$ \\
\hline $\begin{array}{c}\mathbf{i V} / \mathbf{V i} \\
(\mathrm{mmHg} / \mathrm{min})\end{array}$ & $7.2 \pm 2.8$ & $4.0 \pm 2.2$ & $<0.001^{*}$ & $22.2 \pm 6.3$ & $7.6 \pm 8.7$ & $0.048^{*}$ & $<0.001^{*}$ & $<0.001^{*}$ \\
\hline
\end{tabular}


No significant differences were found in any of the chosen parameters during ankle occlusion, which suggests that both the perfusion decrease and recovery occur in a similar way on both groups in terms of magnitude and duration. In both protocols $\mathrm{dV}$ and $\mathrm{iV}$ were consistently lower for group 2, which suggests a lower oxygen extraction capacity in older subjects.

When comparing parameters from both protocols and each group, significantly higher RF, PF, RF-BZ, BZ$\mathrm{PF}, \mathrm{AH}, \mathrm{AH} / \mathrm{AO}, \mathrm{dV}$ and $\mathrm{iV}$ values were found for both groups during the occlusion protocol, as shown in Table 3. No differences were found for BZ and RF-PF in group 1 as well as AO in both groups.

PLR and ankle occlusion are physiologically similar, in the sense that both create a compensatory hyperemia on the onset of recovery. PLR is experimentally more convenient since it is better tolerated by the subjects. These results seem to confirm that the reactive hyperemia profile is posture-dependent, as suggested previously [17]. While sitting upright, blood accumulates in the lower limb, increasing perfusion, while in a supine position blood redistributes throughout the body and lowers lower limb perfusion. These differences in blood distribution explain the more exuberant hyperemia found in the ankle occlusion protocol.

This hyperemic response following occlusion is mostly attributed to the nitric oxide (NO) production by the endothelium ${ }^{[18]}$. For PLR the hyperemia profile was also shown to be related to differences in vessels' transmural pressure ${ }^{[17]}$. One of the hallmarks of microvascular ageing is precisely the endothelial dysfunction, possibly due to a decline in NO and prostanoid pathways ${ }^{[19-21]}$. Our PLR characterization seems to support this notion of age-related drop in the NO production.

Although posture is an important factor to take into account, these results suggest that PLR has a higher sensitivity to distinguish the microvascular reactivity of individuals of different ages.

\section{Conclusion}

Our results seem to confirm the utility of these experimental models to distinguish the microcirculatory function of subjects with different ages. Between the two studied protocols, PLR proved to be more sensitive in de diminuída de recuperação em relação a indivíduos mais jovens.

Não foram encontradas diferenças significativas para nenhum dos parâmetros escolhidos durante a oclusão ao nível do tornozelo, o que sugere que tanto a diminuição da perfusão como a recuperação ocorrem de forma semelhante em ambos os grupos, em termos de magnitude e duração. Em ambos os protocolos Vd e Vi foram consistentemente mais baixas no grupo 2, o que sugere uma menor capacidade de extração de oxigénio em indivíduos mais velhos.

Ao comparar os parâmetros de ambos os protocolos em cada grupo, foram encontrados valores significativamente maiores de FR, PF, FR-ZB, ZB-PF, AH, AH/AO, Vd e Vi para ambos os grupos durante o protocolo de oclusão, como mostra a tabela 3. Não foram encontradas diferenças para ZB e FR-PF no grupo I, bem como para $\mathrm{AO}$ em nenhum os grupos.

A EPP e a oclusão ao nível do tornozelo são fisiologicamente semelhantes, no sentido de que ambas criam uma hiperémia compensatória no início da recuperação. A EPP é experimentalmente mais conveniente, uma vez que é mais bem tolerada pelos indivíduos. Estes resultados parecem confirmar que o perfil de hiperémia reativa é dependente da postura, como sugerido anteriormente ${ }^{[17]}$. Na posição sentada, o sangue acumula-se no membro inferior aumentando a perfusão, enquanto que na posição supina o sangue redistribui-se por todo o corpo e diminui a perfusão do membro inferior. Estas diferenças na distribuição de sangue explicam a hiperémia mais exuberante encontrada no protocolo de oclusão.

Esta resposta hiperémica após oclusão é principalmente atribuída à produção de óxido nítrico (NO) pelo endotélio ${ }^{[18]}$. Para a EPP o perfil de hiperémia mostrou-se estar também relacionado com diferenças na pressão transmural dos vasos ${ }^{[17]}$. Uma das marcas do envelhecimento microvascular é precisamente a disfunção endotelial, possivelmente devido a um declínio nas vias de NO e prostanóides ${ }^{[19-21]}$. A nossa caracterização da EPP parece apoiar esta noção de declínio na produção de NO relacionada com a idade.

Embora a postura seja um fator importante a ter em conta, estes resultados sugerem que a EPP tem uma sensibilidade mais elevada para distinguir a reatividade microvascular de indivíduos de diferentes idades.

\section{Conclusão}

Os resultados parecem confirmar a utilidade destes modelos experimentais para distinguir a função microcirculatória de indivíduos com diferentes idades. Entre os dois protocolos estudados, a EPP provou ser mais sen- 
detecting age-related changes in microcirculatory function. Further studies should be carried out to assess the usefulness of these models in patients with vascular disease.

\section{Conflict of interest}

The authors declare that there are no financial and/or personal relationships that could be viewed as presenting a potential conflict of interest. sível na deteção de mudanças relacionadas com a idade na função microcirculatória. Novos estudos devem ser levados a cabo para avaliar a utilidade destes modelos em pacientes com doença vascular.

\section{Conflito de interesses}

Os autores declaram a inexistência de qualquer tipo de relação financeira ou pessoal que possa representar um potencial conflito de interesses. 


\section{References/ Referências}

1. Gates PE, Strain WD, Shore AC: Human endothelial function and microvascular ageing. Exp Physiol 2009, 94:311-316.

2. Matz RL, Schott C, Stoclet JC, Andriantsitohaina R: Age-related endothelial dysfunction with respect to nitric oxide, endothelium-derived hyperpolarizing factor and cyclooxygenase products. Physiol Res 2000, 49:1118.

3. Holowatz LA. Human cutaneous microvascular ageing: potential insights into underlying physiological mechanisms of endothelial function and dysfunction. J Physiol. 2008; 586(Pt 14): 3301.

4. Rodrigues LM, Pinto PC, Magro JM, Fernandes M, Alves J. Exploring the influence of skin perfusion on transepidermal water loss. Skin Res Technol. 2004;10(4):257-62.

5. Cracowski, J.-L., Minson, C.T., Salvat-Melis, M., Halliwill, J.R., 2006. Methodological issues in the assessment of skin microvascular endothelial function in humans. Trends Pharmacol. Sci. 27, 503-508.

6. Ladurner R, Küper M, Königsrainer I, Löb S, Wichmann D, Königsrainer A, Coerper S, Beckert S. Predictive value of routine transcutaneous tissue oxygen tension (tcpO2) measurement for the risk of non-healing and amputation in diabetic foot ulcer patients with non-palpable pedal pulses. Med. Sci. Monit 2010. 16 (6), CR273-CR277.

7. Berardesca E, Leveque JL, Masson Ph, the EEMCO Group, EEMCO guidance for the measurement of skin microcirculation: Skin Pharmacol AppI Skin Physiol 2001.

8. Rodrigues L, Ferro IZ, Galego N, Pinto P, Silva N, Rey-Salgueiros Y. Study on the application of transcutaneous $\mathrm{pO} 2$ and $\mathrm{pCO} 2$ monitoring to the in vivo functional characterization of the normal human skin. Piel span 1998; 13: 380-388.
9. Rodrigues LM, Pinto PC, Leal A. Transcutaneous flow related variables measured in vivo: the effects of gender. BMC Dermatol. 2001;1:4.

10. Silva H, Ferreira HA, Bujan, J, Rodrigues LM, 2013. Exploring the oxygen challenge test as a microcirculation evaluation model. Biomed Biopharm Res 2013;10 (2), 209215.

11. Yamazaki F. Hyperoxia attenuates endothelial-mediated vasodilation in the human skin. J. Physiol Sci 2007; 57 (1), 81-84.

12. Monnet X, Teboul JL. Passive leg raising. Intensive Care Med 2008; 34 (4), 659-663.

13. Silva H, Ferreira H, Bujan J, Rodrigues LM. Exploring the oxygen challenge test as a microcirculation evaluation model. Biomed Biopharm Res 2013; (10) 2:209-215.

14. Silva, H., Rosado, C., Antunes, J., Rodrigues, L.M., 2014. Exploring human in vivo microcirculation with methyl nicotinate in different perfusion conditions. Biomedb Biopharm Res. 11 (2), 207-214.

15. Silva H, Ferreira H, Bujan MJ, Rodrigues LM. Regarding the quantification of peripheral microcirculation-Comparing responses evoked in the in vivo human lower limb by postural changes, suprasystolic occlusion and oxygen breathing. Microvasc Res. 2015;99:110-7.

16. World Medical Association, 2013. World Medical Association Declaration of Helsinki: ethical principles for medical research involving human subjects. JAMA 310, 2191-2194.
17. Krishnan A, Lucassen EB, Hogeman C, Blaha C, Leuenberger UA. Effects of limb posture on reactive hyperemia. Eur J Appl Physiol. 2011;111(7):1415-20.

18. Mortensen SP, Askew CD, Walker M, Nyberg $\mathrm{M}$, Hellsten $\mathrm{Y}$. The hyperaemic response to passive leg movement is dependent on nitric oxide: a new tool to evaluate endothelial nitric oxide function. J Physiol. 2012; 590(Pt 17):4391-400.

19. Taddei S, Virdis A, Ghiadoni L, Salvetti G, Bernini G, Magagna A, Salvetti A. Agerelated reduction of $\mathrm{NO}$ availability and oxidative stress in humans. Hypertension. 2001;38:274-279.

20. James MA, Watt PA, Potter JF, Thurston H, Swales JD. Endothelial function in subcutaneous resistance arteries from elderly hypertensive and normotensive subjects. Clin Sci. 1997;92:139 - 145.

21. Singh N, Prasad S, Singer DRJ, MacAllister RJ. Ageing is associated with impairment of nitric oxide and prostanoid dilator pathways in the human forearm. Clin Sci. 2002;102:595-600. 